\title{
National surveillance and control costs for highly pathogenic avian influenza H5N1 in poultry: A benefit-cost assessment for a developing economy, Nigeria
}

Olubunmi G. Fasanmi a,b, Olugbenga O. Kehinde c, Agnes T. Laleye a,d, Bassey Ekong e, Syed S. U. Ahmed f, Folorunso O. Fasina gh*

a Department of Production Animal Studies, Faculty of Veterinary Science, University of Pretoria, South, Africa

${ }^{b}$ Department of Animal Health, Federal College of Animal Health and Production Technology, Ibadan, Nigeria

c Department of Veterinary Public Health \& Reproduction, College of Veterinary Medicine, Federal University of Agriculture, Abeokuta, Nigeria.

d National Veterinary Research Institute, Vom, Plateau State, Nigeria.

e Department of Veterinary services, Ministry of Agriculture and Natural Resources, Calabar, Nigeria f Department of Epidemiology \& Public Health, Faculty of Veterinary \& Animal Science, Sylhet Agricultural University, Sylhet, Bangladesh.

g Department of Veterinary Tropical Diseases, University of Pretoria, Onderstepoort 0110, South Africa.

${ }^{\mathrm{h}}$ Emergency Centre for Transboundary Animal Diseases (ECTAD), Food and Agriculture Organisation of the United Nations (FAO), Dar es Salaam, United Republic of Tanzania.

*Corresponding author at: Department of Veterinary Tropical Diseases, University of Pretoria, Onderstepoort 0110, South Africa. Email: daydupe2003@yahoo.co.uk ; Phone: +27 84958 1925; +255686132852. 


\begin{abstract}
We conducted benefit-cost analysis of outbreak and surveillance costs for HPAI H5N1in poultry in Nigeria. Poultry's death directly cost US\$ 939,734.0 due to outbreaks. The integrated disease surveillance and response originally created for comprehensive surveillance and laboratory investigation of human diseases was adapted for HPAI H5N1 in poultry. Input data were obtained from the field, government documents and repositories and peer-reviewed publications. Actual/forecasted bird numbers lost were integrated into a financial model and estimates of losses were calculated. Costs of surveillance as alternative intervention were determined based on previous outbreak control costs and outputs were generated in SurvCost ${ }^{\circledR}$ with sensitivity analyses for different scenarios.

Uncontrolled outbreaks will lead to loss of over US\$ 2.2 billion annually in Nigeria with $47.8 \%$ of the losses coming from eggs. The annual cost of all animal related health activities was <US\$ 99.0 million, only one-third of this amount was linked with H5N1 surveillance and response activities. Recurrent cost was $96.2 \%$ of the total surveillance and response costs, and $31.0 \%$ of the HPAI surveillance cost was spent on personnel with $3.8 \%$ as capital cost. Cost-wisely, routine monitoring and surveillance for HPAI are 68 times more cost effective than to do nothing. Assuming that successful control and eradication of HPAI H5N1 is partially attributable to H5N1 surveillance and response, a quarter or half of the success will result in 17 or 34 times more benefits. Although animal surveillance and response activities for avian influenza appeared expensive, their implementation are economically cost beneficial for developing countries.
\end{abstract}

Key words: Avian influenza H5N1; Benefit-cost analysis; Integrated animal disease surveillance and response; Nigeria.

\title{
Introduction
}

Avian influenza, particularly of the highly pathogenic H5N1 subtypes but also other influenzas have continued to infect poultry production throughout Africa. While Egypt has been confirmed to have endemic HPAI H5N1 situation in poultry (FAO, 2011), re-infections remain the major challenge in certain African countries including Nigeria, Cote d'Ivoire, Ghana, Libya, Burkina Faso, Togo and 
Benin (OIE, 2015). Between December 2014 and May 2016, Nigeria alone lost over 2.7 million birds at a direct cost of at least US\$939,734 and other consequences (OIE, 2016).

As part of the effort to control the continued outbreaks of the H5N1 virus, the internationally acceptable standards stipulated by the FAO/OIE include the following among others: movement restriction, import control, rapid laboratory diagnoses, stamping out of outbreaks, vaccination, compensation, market closure, reporting, compartmentalisation and sustained active and passive surveillance (OIE/FAO, 2007; FAO, 2008; Kanamori and Jimba, 2008). To date, comprehensive phylogenetic and ecological analyses have been conducted (Williams and Peterson, 2009; Cattoli et al., 2009; Couacy-Hymann et al., 2012). The cost associated with losses and excess spending to curtail outbreaks of H5N1 influenza virus have been quantified in the household, backyard and commercial poultry (Rushton et al., 2005; Fasina et al., 2012). In addition, the implementation of surveillance has been suggested (Ferrer et al., 2014; Brown et al., 2015), but a comprehensive cost assessment of such policy has not been documented. It is however pertinent to assess these costs to assist policy makers who are faced daily with difficult political and economic decisions of striking careful balance among the many competing interests. These include; health, social, economic, industrial and political for nations' limited resources and to determine the impacts of proposed and ongoing programmes on avian influenza control (FAO, 2004).

Integrated disease surveillance and response(IDSR) is the strategic tool primarily developed for the utilization of surveillance and laboratory data for the rapid detection, reporting and investigation of preventable and priority diseases in humans (WHO, 2000).Whereas the programme was originally developed to conduct functional, timely and effective surveillance for human communicable and non-communicable diseases in order to enhance crucial decision-making process for national public health, it is opined that the model can be modified for the comprehensive assessment of animal health problems. 
In Nigeria, previous reports have recommended the use of a multidisciplinary and multi-sectoral approach to conduct national surveillance. Such team should consist of a combination of the federal, state and private sectors with the aim of optimization of rapid and accurate detection of cases of HPAI H5N1 outbreaks in poultry, and reporting these outbreaks through the same line of command from the local level to the national office (UNSIC, 2006; The World Bank, 2008; Jonas and Warford, 2014; Brown et al., 2015). Following reports of outbreaks, appropriate authorities should be informed to effect and enforce necessary control measures while the same is notified to the OIE.

A comprehensive and sustained national surveillance programme possesses the benefit of reducing zoonotic threat posed by H5N1 to humans while protecting the poultry industry (UNSIC, 2006; The World Bank, 2008; Jonas and Warford, 2014; Brown et al., 2015). In this instance, we utilized the detailed information from these previous reports, trained and adapted the IDSR model for animal disease (avian influenza H5N1) surveillance using the Nigerian poultry population and outbreak scenarios, estimated the cost of losses using financial modelling and determined the benefit-cost ratio of implementation of surveillance compared with doing nothing as a key aspect of control measure.

\section{Materials and Methods}

\section{Data collection and management}

Primary economic, policy-related and market data were sourced from the field (farms, live bird markets (LBMs), government officials, policy makers and official reports). Secondary data were obtained from the repository of the OIE, FAO, government websites, reports and peer-reviewed publications. All data were entered in Microsoft Excel ${ }^{\circledR}$ and duplicate or incomplete data were first confirmed with the national authorities and corrected or removed where confirmation cannot be 
obtained. All data were entered by two persons and reconfirmed by a third individual for accuracy and consistency. Over 2,765,201 poultry have died or were culled in at least 465 outbreaks which occurred between 24 December 2014 and May 2017 (OIE, 2016).

\section{Estimation of poultry population and determination/confirmation of outbreak}

Nigerian poultry population data for the years 2006 to 2013 were obtained from the FAOSTAT (2016) website. Annual increases or decreases in the poultry populations were calculated and mean difference was obtained for the eight-year period (Supplementary material 1a). The obtained mean difference for the 8 previous years was used to estimate the annual increase to determine the Nigerian poultry populations for 2014 to 2016.

To avoid misclassification, we identified outbreak based on the following definition: Following report(s) of abnormal clinical signs and suspected heightened deaths in poultry, in farms or LBMs, teams of outbreak control and surveillance officers were dispatched to the outbreak sites. The teams were responsible for sample collections, implementation of temporary movement control policies, stamping out activities, and immediate dispatches of the samples to the National Veterinary Research Institute, Nigeria. Diagnoses were based on real-time reverse transcriptase polymerase chain reaction (RRT-PCR) and or egg inoculation for virus isolation (Monne et al., 2015). Typically, diagnostic results were obtained within 24 hours from the receipt of samples. An outbreak is confirmed only if the RRT-PCR result is positive. All negative results were confirmed by a second round of test before they can be confirmed as negative and duplicate results are forwarded to the National agricultural authority for notification to the OIE. All reports from the field that were not confirmed by laboratory assessment were excluded and based on daily count data of outbreaks, an epidemic curve was developed (Figure 1a and 1b). 

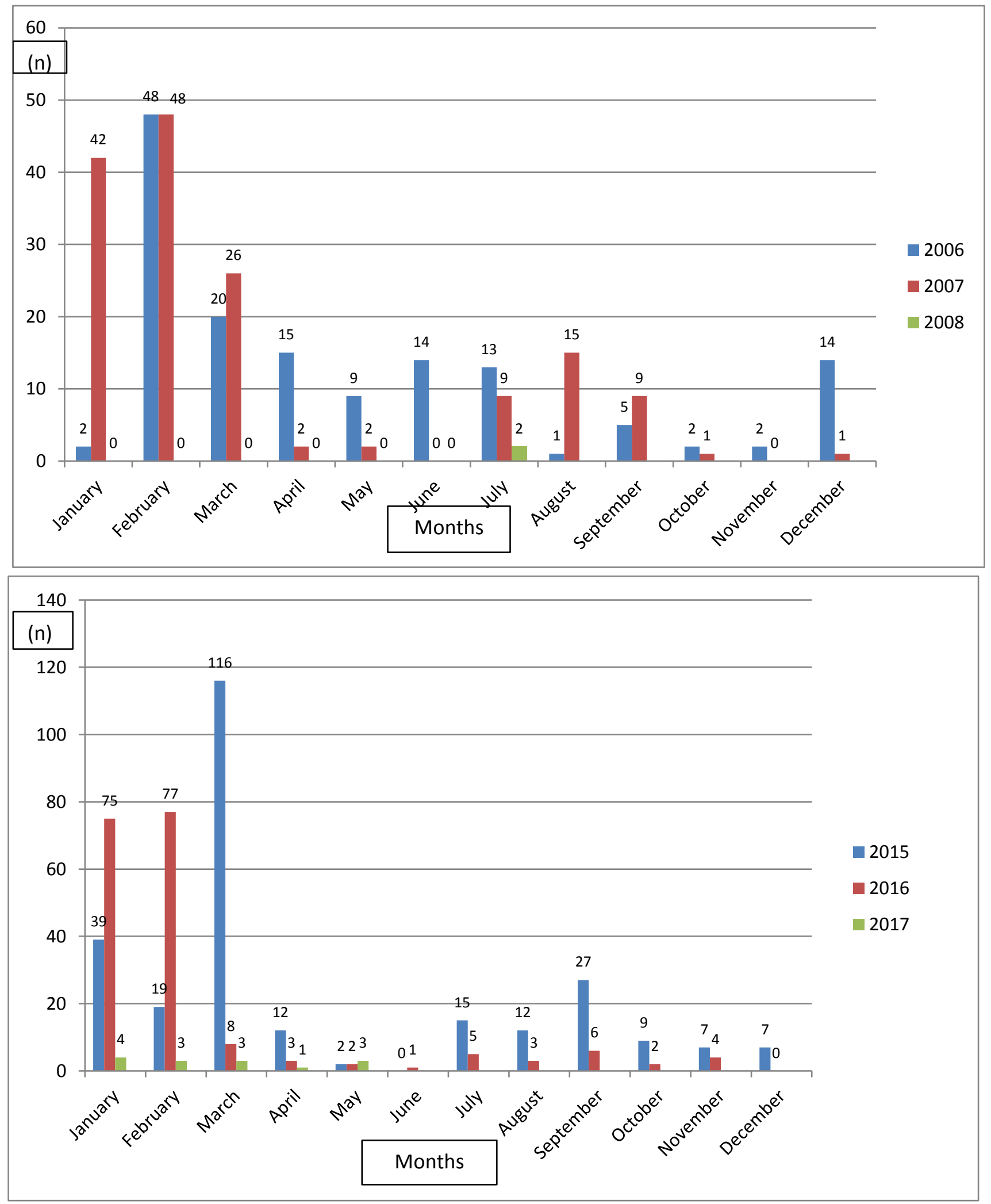

Figure 1a \& b. Epidemic curves of the (a) 2006-2008, and (b) 2015-2017 HPAI H5N1 outbreaks using monthly count data. 


\section{Financial Modelling}

To calculate losses due to avian influenza H5N1, the actual number of birds lost in the recent outbreaks (December 2014 to May 2016; $\mathrm{n}=2,765,201$ birds (4.10\% of the 2016 population for layers/breeders) and the actual poultry population estimate for 2016 were integrated into a partial budget model (Supplementary material 1b). These birds were categorized into bird types (layer,

breeder, broiler and cockerels) for purposes of determining the poultry structure, valuation and payment of compensation. The partial budgeting (partial cost analysis) has been used previously to estimate farm animal losses at farm, regional, national or trans-national levels and empirical assumptions have been made (Rushton et al., 2005; Otte et al., 2008; Fasina et al., 2008). Estimates of direct and indirect losses, outbreak response surveillance costs, diagnostic costs, biosecurity upgrade costs, movement control costs, market closure costs, border control costs, stamping out costs, cleaning and disinfection costs, compensation costs, vaccination costs, industry restructuring costs and transport costs were conducted and integrated (Tambi et al., 1999; Tisdell et al., 1999; Rushton et al., 1999; Hinrichs et al., 2006; McLeod, 2007; Otte et al., 2008). Because poultry is a short cycle animal with a lifespan of approximately 1 year in the farm, the net present values were used and losses of future values were not calculated. However, it was noted that certain costs including but not limited to biosecurity upgrade and industry restructuring as well as training costs, may represent long term investments but does not significantly impact the overall costs since annual costs were used for these variables.

\section{Surveillance costs and benefit-cost analyses}

SurvCost ${ }^{\circledR}$ software was obtained from the website of Centers for Disease Control and Prevention (http://www.cdc.gov/globalhealth/healthprotection/idsr/tools/survcost.html). Comprehensive list of all items for planned surveillance activity in Nigeria was obtained from three official sources: 1) the Integrated National Avian and Pandemic Response Plan, 2007-2009 (UNSIC, 2006); 2) the 
Avian Influenza Control and Human Pandemic Preparedness and Response Project (The World Bank, 2008) and 3) Global Program for Avian Influenza and Human Pandemic Preparedness and Response (The World Bank, 2006). Details of the data were confirmed from experts and workers in the field where necessary. Based on the working knowledge of past surveillance in Nigeria, several cost heads were calculated (Supplementary material 1c; Supplementary material 2) for input into the SurvCost1.0 Beta Version software (Somda, Meltzer and Perry, 2007; Somda et al., 2009) and outputs were generated in personnel cost, transport cost, laboratory cost, treatment cost, media cost, capital cost and recurrent cost. It should be realized that discounted costs was used for capital cost in view of the annualised costs for building and other capital items (Supplementary material 2). Annualised cost refers to annual deduction from the total value of a building spread over an agreed timeline. Farm building usually have a 15-20 years lifespan. The final overall cost estimates for total poultry health services, total disease surveillance activities and total IDSR on avian influenza were calculated in local currency. As at the time of this calculation, the exchange rate was 197.5 naira to $\$ 1$ at the official exchange rate as quoted by the regulatory bank in Nigeria (Central Bank of Nigeria),, after calculations were done in the local currency, conversion were subsequently done to convert to dollars.

A final benefit-cost assessment was conducted to determine whether the implementation of comprehensive HPAI H5N1 IDSR activities was beneficial to the Nigerian poultry industry or not. Scenario and sensitivity analyses were conducted to evaluate whether field and operational changes would affect the benefit cost ratio negatively or positively. Sensitivity analysis was conducted by drawing from a list of variables that may affect field operations in surveillance based on previous experiences of experts. Attributable percentage of effectiveness and reduced losses, increase in personnel costs, transport costs, media and laboratory costs, capital investment costs and overall surveillance costs were measured individually to produce new costs of surveillance. 
New benefit-cost ratios (BCR) were generated based on the method described previously and percentage differences were calculated by comparing the new BCR against the standard BCR.

\section{Results}

A total of over 2.7 million poultry have died or were culled in at least 465 documented outbreaks which occurred between 24 December 2014 and May 2016. Earlier outbreaks of 2006-2008 and that of 2014-2017 followed a similar trend. Details of the outbreaks are available on the website of World Organization for Animal Health (OIE, 2016; Figure 1a and 1b). Considering the commercial sector of the Nigerian poultry industry which caters for approximately $40 \%$ of the total poultry population ( $n=168,536,733)$, potential losses were estimated to be over US\$ 2.2 billion for a potential national epidemic of HPAI H5N1 in 2016 (Table 1). However, to date, in the on-going outbreaks, just over $4.1 \%$ of the commercial poultry have died or were culled at an estimated US\$940,000.00. The huge proportion of the losses are attributed to wasted and potential eggs for the year (47.8\%) (Table 1). Whereas the annual cost of all animal related health activities may be over US\$ 99 million, approximately a third of this amount is attributed directly to avian influenza H5N1 surveillance and response activities. Recurrent cost was approximately $96.2 \%$ of the total cost of IDSR for avian influenza H5N1 in Nigeria and over 31\% of the avian influenza surveillance cost was spent on personnel while the capital cost was 3.8\% (Table 2; Figure 2). 
Table 1. Potential losses and costs associated with the HPAI H5N1 avian influenza outbreaks based on the commercial poultry population in Nigeria, 2016.

\begin{tabular}{|c|c|c|c|c|c|c|}
\hline Cost item & Variables & Number & $\begin{array}{c}\text { Unit } \\
\text { cost }(\$)\end{array}$ & Total cost $(\$)$ & Calculation/assumption & Reference \\
\hline \multirow[t]{5}{*}{ Direct } & Eggs (trays) & $332,185,836$ & 3.3 & $1,096,213,257.81$ & $\begin{array}{c}\text { [Total no of } \\
\text { layer*75\%*80\%hdp*365)/30]*\$3.30] }\end{array}$ & \multirow{5}{*}{$\begin{array}{l}\text { Tambi et al., 1999; Tisdell et } \\
\text { al., 1999; Rushton et al., } \\
\text { 1999; } \\
\text { Hinrichs, et al., 2006; } \\
\text { McLeod, 2007; } \\
\text { Fasina et al., 2008; } \\
\text { Otte et al., 2008; } \\
\text { Fasina et al., 2012 }\end{array}$} \\
\hline & pullet chicks & $415,232,295$ & 1.24 & $514,888,045.34$ & $\begin{array}{c}\text { [Total no of } \\
\text { breeders } * 75 \% * 75 * 80 \% * 50 \% * 365) * \$ \\
1.24]\end{array}$ & \\
\hline & broiler/cockerels & & & & $\begin{array}{l}\text { Assuming that } 50 \% \text { is immature and } \\
50 \% \text { is matured before losses }\end{array}$ & \\
\hline & immatured & $8,426,835$ & 1.52 & $12,808,789.20$ & Total no of bx/cx $* 50 \% * \$ 1.52$ & \\
\hline & matured & $8,426,835$ & 7.87 & $66,319,191.45$ & Total no of bx/cx*50\%*\$7.87 & \\
\hline \multicolumn{7}{|l|}{ Indirect } \\
\hline & Glut & 0 & 0 & 0 & $\mathrm{Nil}^{*}$ & \\
\hline \multicolumn{7}{|l|}{ Intangible } \\
\hline & Replacement & & & & & \\
\hline & P.O.L Layers & $45,504,909$ & 5.58 & $253,917,392.22$ & \multirow{3}{*}{$\begin{array}{c}\text { Total no of layer*N1100 (\$5.58) } \\
\text { Total no. Of breeder*N1900 (\$9.64) } \\
\text { Bx/cx not calculated because they are } \\
\text { short cycled in the farm and meat was } \\
\text { evaluated above already. }\end{array}$} & \multirow{3}{*}{$\begin{array}{l}\text { Rushton et al., 2005; } \\
\text { McLeod, 2007; } \\
\text { Fasina et al., 2008 }\end{array}$} \\
\hline & P.O.L Breeders & $5,056,101$ & 9.64 & $48,740,813.64$ & & \\
\hline & broiler/cockerels & Nil & Nil & Nil & & \\
\hline & Downtime of facilities & $67,414,680$ & 0.76 & $12,808,789.20$ & \multirow[t]{2}{*}{$\begin{array}{l}\text { Total no of commercial flock } \\
\quad * 3 / 12 * \mathrm{~N} 150(\$ 0.76)\end{array}$} & Fasina et al., 2008 \\
\hline & Destruction and disposal & & & & & \\
\hline Compensation & $\begin{array}{c}\text { Compensation for slaughtered } \\
\text { chickens }\end{array}$ & & & $286,339,639.88$ & & $\begin{array}{l}\text { Kanamori \& Jimba, 2007; } \\
\text { McLeod, } 2007 \\
\end{array}$ \\
\hline $\begin{array}{l}\text { Foregone } \\
\text { costs }\end{array}$ & & $\begin{array}{r}45,504,909 \\
5,056,101 \\
\end{array}$ & $\begin{array}{l}14.94 \\
18.74 \\
\end{array}$ & $1,482,803752.00$ & \multicolumn{2}{|c|}{$\begin{array}{l}\text { (Total no of layers*125g/1000*365 days*14.94/25kg/bag) + (Total no } \\
\text { of breeders } * 175 \mathrm{~g} / 1000 * 365 \text { days } * 18.74 / 25 \mathrm{~kg} / \mathrm{bag})\end{array}$} \\
\hline \multicolumn{2}{|l|}{ Total } & \multicolumn{5}{|c|}{$2,292,035,918.74-1,482,803,752.00 *=809,232,165.00$} \\
\hline
\end{tabular}

The calculations were based on the commercial poultry population in Nigeria for the year $2016(n=67414680)$. Cost of glut $=$ Nil $*($ Farmers and the consumers are now refractory to the shock associated with the initial outbreaks of HPAI H5N1 and its economic effects).P.O.L = Point of lay birds; hdp = hen day production; bx/cx = broiler/cockerel

*Note that foregone costs include assumed feed requirement per annum for breeders and layers (calculated here and such similar costs).These are input costs which should be calculated per annum and deducted from the overall losses since assumed annual production is factored into the overall losses. 
Table 2. Table of annual summary of cost estimates for total animal health and HPAI H5N1 Integrated disease surveillance and response programme, Nigeria, 2016

\begin{tabular}{|c|c|c|c|c|}
\hline Resources & $\begin{array}{l}\text { Total animal health activities cost } \\
\text { (USD) }\end{array}$ & $\begin{array}{l}\text { All animal disease surveillance cost } \\
\text { (USD) }\end{array}$ & $\begin{array}{l}\text { HPAI H5N1 IDSR cost } \\
\text { (USD) }\end{array}$ & $\begin{array}{l}\text { Resource as \% of total } \\
\text { IDSR }\end{array}$ \\
\hline \multicolumn{5}{|l|}{ Recurrent items } \\
\hline Personnel & $43,465,756.35$ & $22,818,431.08$ & $10,507,845.99$ & 31.27 \\
\hline Office & $4,700,253.80$ & $2,566,192.89$ & $1,992,214.46$ & 5.93 \\
\hline Transport & $702,633.75$ & $585,739.83$ & $537,930.88$ & 1.60 \\
\hline Media & $8,853,046.80$ & $7,930,450.02$ & $5,916,139.23$ & 17.60 \\
\hline Laboratory & $6,755,350.66$ & $6,220,793.82$ & $5,580,807.95$ & 16.61 \\
\hline Treatment & $32,710,659.90$ & $18,017,331.98$ & $7,805,250.56$ & 23.22 \\
\hline Recurrent cost & $97,187,701.25$ & 58138939.62 & 32,340,189.07 & 96.23 \\
\hline \multicolumn{5}{|l|}{ Capital items } \\
\hline Building & $227,692.06$ & $204,922.85$ & $174,184.43$ & 0.52 \\
\hline Vehicles & $380,628.00$ & $372,484.27$ & $274,856.05$ & 0.82 \\
\hline Equipment & $1,418,663.05$ & $967,487.69$ & $818,192.28$ & 2.43 \\
\hline Capital cost & $2,026,983.11$ & $1,544,894.81$ & $1,267,232.75$ & 3.77 \\
\hline All resources & 99.214 .684 .35 & $59,683,834.43$ & $33,607,421.82$ & \\
\hline Cost per chicken & 1.47 & 0.89 & 0.50 & \\
\hline
\end{tabular}




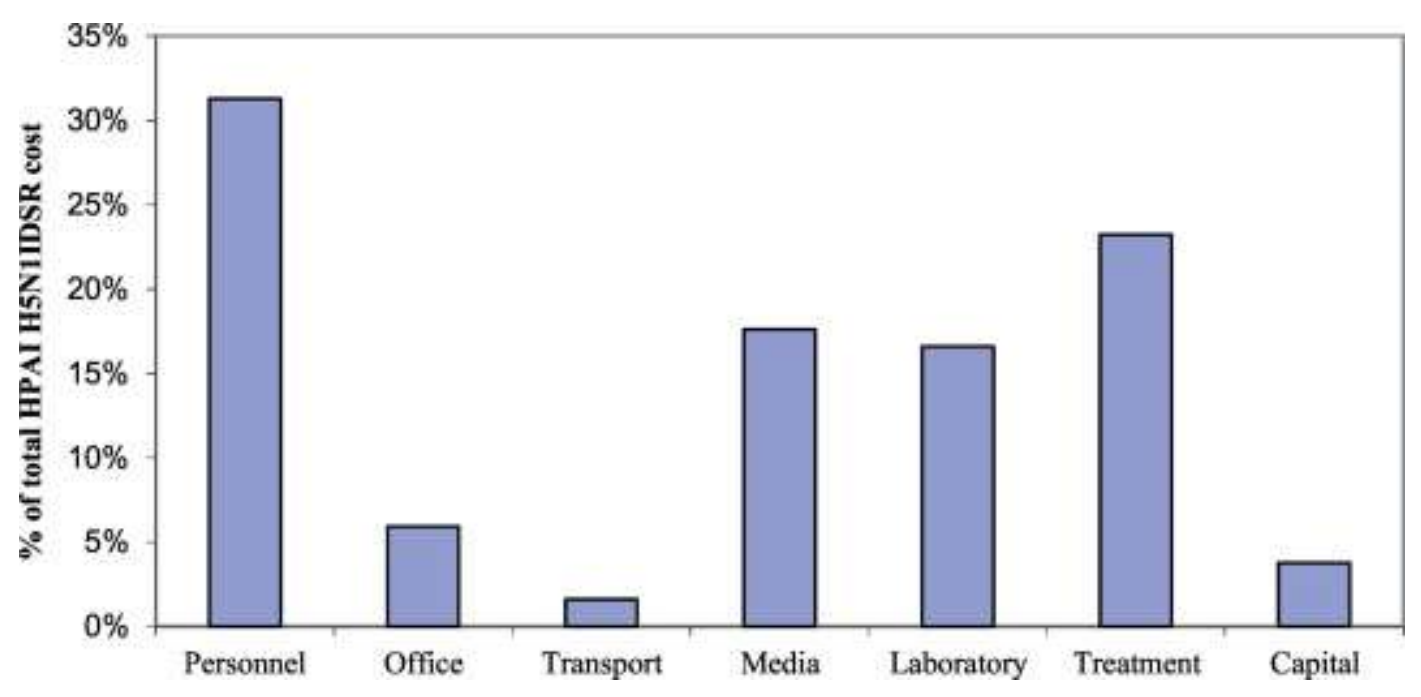

Fig. 2. Graphical representation of resource allocation in HPAI H5N1 Integrated disease surveillance and response, Nigeria, 2016.

Overall, it is at least 24 times more cost effective to consider an annual comprehensive surveillance based on modified IDSR than to do nothing and allowed HPAI H5N1 to continue unabated in the national flock. Assuming that for the successful control, only a quarter or half of the success of control efforts is attributable to HPAI H5N1 IDSR, the programme will still be 6 times or 12 times more beneficial respectively (Table 3). In view of the dynamic environment and changed economic parameters, different scenarios were presented for and against the HPAI H5N1 IDSR and outcomes were presented in Table 3. Estimated scenarios of reduced losses due to HPAI H5N1 by 50\% on the effectiveness of surveillance activities reduced by $50 \%$ will result in a benefit-cost of 12 . If the personnel cost is increased by $20 \%$ there will be a reduction in benefit-cost ratio from 24 to $\approx 23$, while an increase in surveillance transportation cost by $100 \%$ will marginally reduce the benefitcost ratio by a factor of $<1$. An increase in overall surveillance cost by about $150 \%$ will reduce the benefit-cost ratio to just $\approx 10$ (Table 3 ). 
Table 3. Sensitivity and benefit-cost analyses under different field and operational scenarios

\begin{tabular}{|c|c|c|c|c|c|c|c|}
\hline Scenario & $\begin{array}{l}\text { Current Annual } \\
\text { losses per annum } \\
\text { (US\$) }\end{array}$ & $\begin{array}{c}\text { Current } \\
\text { surveillance } \\
\text { cost per } \\
\text { annum (US\$) }\end{array}$ & $\begin{array}{c}\text { Current } \\
\text { Benefit- } \\
\text { cost ratio } \\
\text { per annum }\end{array}$ & $\begin{array}{l}\text { New losses per } \\
\text { annum (US\$) }\end{array}$ & $\begin{array}{c}\text { New } \\
\text { surveillance } \\
\text { cost per } \\
\text { annum (US\$) }\end{array}$ & $\begin{array}{c}\text { New } \\
\text { Benefit- } \\
\text { cost ratio } \\
\text { per annum }\end{array}$ & $\begin{array}{c}\text { Percentage } \\
\text { reduction } \\
\text { in benefit- } \\
\text { cost }\end{array}$ \\
\hline Current scenario & $809,232,165.00$ & \multirow{9}{*}{$33,607,422.00$} & \multirow{9}{*}{24.08} & Reference & Reference & Reference & Reference \\
\hline Losses reduces by $50 \%$ or surveillance is only $50 \%$ effective & \multirow{8}{*}{$2,292,035,918.74$} & & & $404,616,082.00$ & $33,607,422.00$ & 12.04 & 50.00 \\
\hline Personnel cost increased by $20 \%$ & & & & $809,232,165.00$ & $35,708,991.20$ & 22.66 & 5.89 \\
\hline Transport cost increased by $100 \%$ & & & & $809,232,165.00$ & $34,145,353.00$ & 23.70 & 1.58 \\
\hline Media cost increased by $25 \%$ & & & & $809,232,165.00$ & $35,086,456.75$ & 23.06 & 4.22 \\
\hline Laboratory cost increased by $50 \%$ & & & & $809,232,165.00$ & $36,397,826.00$ & 22.23 & 7.67 \\
\hline Capital cost increased by $200 \%$ & & & & $809,232,165.00$ & $36,141,888.00$ & 22.39 & 7.01 \\
\hline Overall surveillance cost increased by $100 \%$ & & & & $809,232,165.00$ & $67,214,844.00$ & 12.04 & 50.00 \\
\hline 0verall surveillance cost increased by $150 \%$ & & & & $809,232,165.00$ & $84,018,555.00$ & 9.63 & 60.00 \\
\hline
\end{tabular}

With the model scenario, it is approximately 24 times better to implement integrated disease surveillance for HPAI H5N1. 


\section{Discussion}

We have evaluated the implementation of routine and comprehensive national surveillance using the structured surveillance and response activities for HPAI H5N1 in Nigeria. A comprehensive surveillance system in this regards refers to a multi-sectoral approach in which there are two-way chain of command systems from the federal to the grass root level taking into consideration the recommendation of Brown et al., (2015). Nigeria currently has one central veterinary laboratory with over thirty out-stations, five regional laboratories (veterinary teaching hospitals), 37 state desk offices and many randomly dispersed surveillance points to support comprehensive surveillance and response activities. Whereas the developing economies like Nigeria may argue against routine animal disease surveillance in view of the huge costs involvement, diminishing national resources, other competing interests and poor veterinary infrastructures (IOM, 2007; Fadiga et al., 2014), the benefit accruable to carefully planned surveillance and response activities in animal health is justifiably cost beneficial (Pavade et al., 2016). Other workers have provided similar evidence to support the implementation of integrated animal disease surveillance and strengthened animal health services in developing countries (FAO, 1991; de Balogh et al., 2013). Poultry is very important in the Nigerian economy and its national expansion at 3.2 percent outpaces the global increase of 2.2 percent. It meets food security need, enhance livelihood and is particularly important in resource poor settings. Its meat and eggs are the most consumed animal protein and are not restricted by any religion or culture in Nigeria. Poultry industry contributed about 25\% of the country's Agricultural GDP (FAO, 2010; Essay UK, 2018), and the country produces above 550,000mt of poultry meat and 700,000mt of eggs per annum supplying Cameroon, Togo, Benin, Benin Republic, Niger and many other countries in the sub-region (FAO, 2010). Hence a major uncontrolled outbreak of infectious disease to the industry will have a far-reaching consequence on the national economy. 
Thirteen African countries have experienced epidemics of HPAI H5N1 with sustained endemicity or re-infections in some countries, and globally, three continents have been challenged by the disease with global impacts (FAO, 2013; von Dobschuetz et al., 2015). Monitoring of the virus and its characteristics, early detection and effective control of avian influenza are hinged on effective surveillance. However, most bio-surveillance in developing countries only occur episodically and only after vast outbreak. The funds for the control and eradication efforts largely originated to date from international donors (UNSIC, 2006; The World Bank, 2008; Jonas and Warford, 2014; Pavade et al., 2016; Supplementary materials 1d-f). This dependence on donor funding and an unplanned surveillance and response system created limitations that affect outbreak response (the speed and accuracy with which the initial and subsequent outbreaks were detected, communicated, and controlled) (Brown et al., 2015). Furthermore, because the donor funds for surveillance were time bound, African countries and other developing and countries in transition will benefit from an improved investment in animal disease surveillance, as well as planned and sustained anticipatory actions and rapid turn-around time in disease detection through active and passive surveillance (Pavade et al., 2016). For example, Nigeria took a loan of US\$50 million under the Global Program for Avian influenza and Human Pandemic Preparedness and Response (GPAI) in 2006 (The World Bank, 2006). An investment of over US $\$ 33$ million for continuous and rapid integrated disease surveillance and response for avian influenza in the same year may possibly have saved the country the sum of approximately US\$ 2 billion from outputs from poultry, an investment that would have been at least 40 times its worth.

We have presented evidence to support comprehensive avian influenza surveillance in Nigeria using the economic cost analyses with certain limitations. In the course of our evaluations, animal health economic data appeared unstructured and lacking and this presented some limitations. To overcome this barrier, we sourced our information from reputable international donor organisations, field experts, national officers and persons directly involved in avian influenza H5N1 
outbreak control program in Nigeria. Although many countries have indicated the conduct of passive and active surveillance to target influenza viruses (von Dobschuetz et al., 2015), empirical economic data to support the conduct of surveillance were lacking in many respects. It is advocated that a standard format of global reporting should be created and used in harnessing animal health economic data, similar to those available for genetic and epidemiological data which are searchable in the international databases for animal diseases. Present databases available in multi-country organisation platforms should be used.

Although HPAI H5N1 has zoonotic potentials, and human pandemic preparedness was part of the national surveillance programme, we did not evaluate for human-related avian influenza H5N1 in this analysis because very limited data exist for H5N1 cases of influenza in Nigeria with only one case and one death reported (Breiman et al., 2007). As previously advocated by Pavade et al., (2016), and Breiman and colleagues (2007), global commitment to animal and human influenza surveillance become imperative for development, food security and poverty alleviation. In addition, regional approach to the integration of integrated animal disease surveillance and response as well as the inclusion of surveillance for other diseases together with other principles of good farming practices can further extend the benefit associated with the implementation of H5N1 comprehensive disease surveillance in poultry.

We have shown evidence to support the implementation of surveillance despite the costs involved. While this work may serve as baseline for evidence-based practice in the industry, further more integrative simulations which involve multidisciplinary stakeholders from the industry is warranted. Such effort had been implemented by the World Bank previously at global level and countries can devolve such analysis to country situations (Jonas and Warford, 2014). Because no control method is effective singly, testing different mixes of surveillance and control efforts are necessary considering the different dynamics in the field. This multi-activity implementation will 
guide different cost allocation (biosecurity, prevention of re-introduction, training, and such others). While the losses to the industry have been estimated in this work, other indirect losses are available and are distributed in the society. Macro-economists and policy makers should engage discussion in this respect to have a comprehensive overview of associated costs of diseases in the animal sector. This will become beneficial to decision-makers in guiding advocacy for public investment in HPAI prevention (Tiongco, 2008; Jonas and Warford, 2014).

In conclusion, integrated disease surveillance against poultry disease like avian influenza comes at huge costs; however, it is economically beneficial to implement it nationally than to allow the current waves of outbreaks to continue unabated. Additional benefits like the protection of genetic resources, prevention of trans-national spread and zoonoses as well as sustained livelihoods will also justify such investment.

\section{References}

Breiman, R.F., Nasidi, A., Katz, M.A., Njenga, M.K., Vertefeuille, J., 2007. Preparedness for highly pathogenic influenza pandemic in Africa. Emerg. Infect Dis. 13(10), 14531458http://dx.doi.org/10.3201\%2Feid1310.070400

Brown, M., Moore, L., McMahon, B., Powell, D., LaBute, M., Hyman J. M., Rivas A., Jankowski M., Berendzen, J., Loeppky, J., Manore, C., Fair, J., 2015. Constructing rigorous and broad biosurveillance networks for detecting emerging zoonotic outbreaks. PLoS ONE10(5): e0124037doi:10.1371/journal.pone.0124037

Cattoli, G., Monne, I., Fusaro, A., Joannis, T.M., Lombin, L.H., Aly, M.M., et al.,2009. Highly Pathogenic Avian Influenza Virus Subtype H5N1 in Africa: A Comprehensive Phylogenetic Analysis and Molecular Characterization of Isolates. PLoS ONE 4(3): e4842. doi:10.1371/journal.pone.0004842

Couacy-Hymann, E., Kouakou, V.A., Aplogan, G.L., Awoume, F., Kouakou, C.K., Kakpo, L., et al. Surveillance for influenza viruses in poultry and swine, West Africa, 2006-2008. Emerg Infect Dis [serial on the Internet]. 2012 Sep [date cited].http://dx.doi.org/10.3201/eid1809.111296 
De Balogh, K., Halliday, J., Lubroth, J.,2013. Integrating the surveillance of animal health,foodborne pathogens and foodborne diseases in developing and in-transition countries. Rev. sci tech Off. Int. Epiz, 32(2), 539-548.

Essay UK, Poultry Industry In Nigeria. Available: http://www.essay.uk.com/freeessays/economics/poultry-industry-nigeria.php. Accessed 20.0318.

FAO (Food and Agriculture Organization of the United Nations), 1991. Development of Animal Health and Production (Surveillance). In: Guidelines for Strengthening Animal Health Services in Developing Countries. FAO, Rome Italy. Available at: http://www.fao.org/docrep/u2200e/u2200e00.htm\#Contents. Accessed 11.04.16.

FAO (Food and Agriculture Organisation of the United Nations), 2004. Social and economic impacts of Avian Influenza Control. Report of the FAO Workshop, 8-9 December 2004, Bangkok, Thailand. Available at: http://www.fao.org/avianflu/documents/Economic-and-social-impacts-ofavian-influenza-Geneva.pdf. Accessed 28.04.2016.

FAO (Food and Agriculture Organisation of the United Nations), 2008. Biosecurity for Highly Pathogenic Avian Influenza: Issues and Options. FAO Animal Production and Health Paper 165. Available at: http://www.fao.org/3/a-i0359e.pdf. Accessed 26.03.16.

FAO (Food and Agriculture Organisation of the United Nations), 2010. Agribusiness Handbook: Poultry meat and Eggs. Investment Centre Division. FAO. Rome, Italy.

FAO (Food and Agriculture Organization of the United Nations), 2011. Approaches to controlling, preventing and eliminating H5N1 highly Pathogenic Avian Influenza in endemic countries. Food and Agriculture Organization of the United Nations, Rome, Animal Production and Health Paper No 171. Available at: http://www.fao.org/docrep/014/i2150e/i2150.pdf . Accessed 09.04.16.

FAO (Food and Agriculture Organization of the United Nations), 2013.Fifth Report of the Global Programme for the Prevention and Control of highly pathogenic avian influenza, January 2011January 2012. Available at: http://www.fao.org/docrep/017/i3139e/i3139e.pdf. Accessed $\underline{04.04 .16 .}$

FAO (Food and Agriculture Organization of the United Nations), 2013. Mapping Influenza A (H5N1) virus transmission pathways and critical control points in Egypt. Animal Production and 
Health Working Paper No. 11. Rome, Italy. Available at:

http://www.fao.org/docrep/017/i3272e/i3272e.pdf. Accessed 04.04.2016.

FAO (Food and Agriculture Organization of the United Nations), 2016. FAOSTAT Production data: Live Animals (Nigeria, Poultry birds + (Total) 2006, 2007, 2008, 2009, 2010, 2011, 2012, 2013. Available at: http://faostat.fao.org/site/573/DesktopDefault.aspx?PageID=573\#ancor. Accessed 10.04.16.

Fadiga, M.L., Okike, I., Bett, B., 2014. An expost economic assessment of the intervention against highly pathogenic avian influenza in Nigeria. Bio-based and Appl. Econs. 3(1), 45-61

Fasina, F.O., Ali, A.M., Yilma, J.M., Thieme, O., Ankers, P.,2012. The cost-benefit of biosecurity measures on infectious diseases in the Egyptian household poultry. Prev. Vet. Med. 103,178191.

Fasina, F.O., Sirdar, M.M., Bisschop, S.P.R.,2008. The financial cost implications of the highly pathogenic notifiable avian influenza H5N1 in Nigeria. Onderstepoort J. Vet. Res. 75, 39-46.

Ferrer, E., Alfonso, P., Ippoliti, C., Abeledo, M., Calistri, P., Blanco, P., Conte, A., Sanchez, B., Fonseca, O., Perdeco, M., Perez, A., Fernandez, O., Giovannini, A., 2014.Development of an active riskbased surveillance strategy for avian influenza in Cuba. Prev. Vet. Med., 116(1), 161-167.

Hinrichs, J., Sims, L., McLeod, A.Some Direct Costs of Control for Avian Influenza. 2006. Available at: http://www.fao.org/docs/eims/upload/213699/agal AI 210906.pdf. Accessed 21.03.16.

Institute of Medicine (IOM), Forum on Microbial Threats. 2007. Global Infectious Disease Surveillance and Detection: Assessing the Challenges-Finding Solutions, Workshop Summary. Washington (DC): National Academies Press (US); 2007. Summary and Assessment. Available from: http://www.ncbi.nlm.nih.gov/books/NBK52862/. Accessed 09.04.16.

Jonas O., Warford, L., 2014. Global program for Avian Influenza control and human pandemic preparedness and response : project accomplishments. Washington, DC: World Bank Group. Available at: http://documents.worldbank.org/curated/en/2014/09/23980557/globalprogram-avian-influenza-control-human-pandemic-preparedness-response-projectaccomplishments. Accessed 09.04.16. 
Kanamori,. S, Jimba, M., 2008. Compensation for avian influenza cleanup [letter]. Emerg Infect Dis [serial on the Internet]. Available from http://www.cdc.gov/eid/content/13/2/341.htm. Accessed 09.04.16.

McLeod, A.,2007. GDLN Third Seminar Series on Avian and Human Influenza, Compensation Policies. Available at: http://www.worldbank.org/en/topic/pandemics/brief/third-seminarseries-on-avian-human-influenza-compensation-policies-2007. Accessed 3.04.16.

Monne, I., Meseko, C., Joannis, T., Shittu, I., Ahmed, M., Tassoni, L., et al., 2015. Highly pathogenic avian influenza A(H5N1) virus in poultry, Nigeria, 2015 [letter]. Emerg Infect Dis.]http://dx.doi.org/10.3201/eid2107.150421 Accessed 11.04.16

National Salaries, Incomes and Wages Commission, 2015. Salary Structures and Emoluments of Federal Government Salaries (Policy Documents). Available at: http://www.nsiwc.gov.ng/Policy docs.php. Accessed on 25.03.16.

OIE (World Organisation for Animal Health) /Food and Agriculture Organisation of the United Nations (FAO), 2007. The Global Strategy for Prevention and Control of H5N1 Highly Pathogenic Avian Influenza. Available at: http://web.oie.int/eng/avian influenza/Global Strategy fulldoc.pdf. Accessed 26.03.16.

OIE (World Organisation for Animal Health), 2015. Update on highly pathogenic avian influenza in animals (Type H5 and H7). Available from: URL: http://www.oie.int/animal-health-in-the466world/update-on-avian-influenza/2015/. Accessed 03.04.16

OIE (World Organization for Animal Health), 2016. Update on Highly Pathogenic Avian Influenza in Animals (type H5 and H7). Available at: http://www.oie.int/en/animal-health-intheworld/update-on-avian-influenza/2016/. Accessed on 04.0416.

Otte, J., Hinrichs, J., Rushton, J., Roland-Holst, D., Zilberman, D., 2008. Impacts of avian influenza virus on animal production in developing countries. CAB Rev: Perspect. Agric. Vet.Sci. Nutri. Nat. Res. 3, 080.doi: 10.1079/PAVSNNR20083080.

Pavade, G., Weber-Vintzel, L., Hamilton, K., Dehove, A., Zepeda, C. (2016). OFFLU review of avian influenza surveillance and epidemiological projects in some European, African and Asian countries. Available at: http://www.oie.int/doc/ged/D9836.PDF. Accessed 12.04.16. 
Rushton, J., Thornton, P.K., Otte, M.J., 1999.Methods of economic impact assessment. Rev. sci tech Off. Int. Epiz, 18, 315-342

Rushton, J., Viscarra, R., GuerneBleich, E., McLeod, A.,2005. Impact of avian influenza outbreaks inthe poultry sectors of five South East Asian countries (Cambodia, Indonesia, Lao PDR, Thailand, Viet Nam) outbreak costs, responses and potential long term control. W. Poult. Sci. J. $61,491-514$

Somda, Z.C., Meltzer, M.I., Perry, H.N., Messonnier, N.E., Abdulmumini,U., Mebrahtu,G., Sacko, M., Touré, K., Ouédraogo, K. S., Okorosobo, T., Alemu, W., Sow, I.,2009. Cost analysis of an integrated disease surveillance and response system: case of Burkina Faso, Eritrea, and Mali. Cost Effect. Res. Alloc.7, 1. doi: 10.1186/1478-7547-7-1.

Somda, Z.C., Meltzer, M.I.,Perry,H.N.,2007. SurvCost 1.0: a manual to assist country and district public health officials in estimating the cost of the implementation of Integrated Disease Surveillance and Response systems (Beta test version). Centers for Disease Control and Prevention, National Center for Prevention, Detection and Control of Infectious Diseases (NCPDCID), Division of Emerging Infections and Surveillance Services (DEISS), U.S. Department of Health and Human Services; 2007. Available at: http://www.cdc.gov/globalhealth/healthprotection/idsr/pdf/survcost-manual--jan-2008.pdf. Accessed 07.04.16.

Tambi, E.N., Maina, O.W., Mukhebi, A.W., Randolph, T.F., 1999. Economic impact assessment of rinderpest control in Africa. Rev. sci tech Off. Int. Epiz, 18, 458-477.

The World Bank. 2006. Global Program for Avian influenza and Human Pandemic Preparedness and Response (GPAI). Available at: http://siteresources.worldbank.org/EXTAVIANFLU/Resources/31244401172616767012/NigeriaPAD.pdf.Accessed 26.04.16

The World Bank, 2008. Nigeria - Avian Influenza Control And Human Pandemic Preparedness And Response Project: Nigeria - Avian Influenza Control And Human Pandemic Preparedness And Response Project : procurement plan (English). Available at:http://web.worldbank.org/external/projects/main?pagePK=51351038\&piPK=51351152\&t heSitePK=40941\&projid=P100122. Accessed 22.03.16. 
Tisdell, C.A., Harrison, S.R., Ramsay, G.C., 1999. The economic impacts of endemic diseases and disease control programmes. Rev. Sci. Tech. Off. Int. Epizoot. 18, 380-398.

Tiongco, M., 2008. Costs and benefits of HPAI prevention and control measures: A methodological review. Africa/Indonesia Team Working Paper No. 13. Available at: https://assets.publishing.service.gov.uk/media/57a08b93ed915d622c000d83/wp13 IFPRI.pd f. Accessed 20.03.2018

United Nations System Influenza Coordination (UNSIC) Office. (2006). Integrated National Avian and Pandemic Influenza Response Plan - 2007 -2009. Available at: https://www.google.co.za/url?sa=t\&rct=j\&q=\&esrc=s\&source=web\&cd=3\&cad=rja\&uact=8\&ve d=0ahUKEwiJ3oy4ndTLAhUKPxoKHV-SCocQFggnMAI\&url=http\%3A\%2F\%2Fwww.uninfluenza.org\%2Fsites\%2Fdefault\%2Ffiles\%2Ffiles\%2FNational Integrated Plan for AHINigeria.doc\&usg=AFQjCNHT2zXiL0PkJSsXC94bsoK5wX65jg\&sig2=4W44JafGFunONksNJWztTg. Accessed 20.04.16

Von Dobschuetz,S., De Nardi, M., Harris, K. A., Munoz, O., Breed, A. C., Wieland, B., Dauphin, G., Lubroth, J,Stärk, K. D. C., the Flurisk Consortium,2015. Influenza surveillance in animals: what is our capacity to detectemerging influenza viruses with zoonotic potential? Epidemiol. Infect. $143,2187-2204$.

Williams, R.A.J., Peterson, A.T.,2009. Ecology and geography of avian influenza (HPAI H5N1) transmission in the Middle East and Africa. Inter. J. Health Geographics, 8:47.DOI: $10.1186 / 1476-072 X-8-47$

World Health Organization,2000.An integrated approach to communicable disease surveillance. Weekly Epidemiol. Rec. 75, 1-8. Available at: http://www.who.int/docstore/wer/pdf/2000/wer7501.pdf. Accessed 26.03.16. 